\title{
PHOTOSYNTHETIC PERFORMANCE OF MANGROVES Rhizophora mangle AND Laguncularia racemosa UNDER FIELD CONDITIONS ${ }^{1}$
}

\author{
Antelmo Ralph Falqueto ${ }^{2}$, Diolina Moura Silva ${ }^{3}$, Renata Venturim Fontes ${ }^{4}$
}

\begin{abstract}
In mature mangrove plants Rhizophora mangle L. and Laguncularia racemosa Gaerth. growing under field conditions, photosystem 2 (PS2) photochemical efficiency, determined by the ratio of variable to maximum fluorescence $\left(F_{v} / F_{m}\right)$, increased during the day in response to salinity in the rainy seasons. During the dry season, fluorescence values $(F o$ ) were higher than those observed in rainy season. In addition, $F o$ decreased during the day in both season and species, except for $R$. mangle during the dry season. A positive correlation among $F_{v} / F_{m}$ and salinity values was obtained for $R$. mangle and L. Racemosa during the dry and rainy seasons, showing that photosynthetic performance is maintained in both species under high salinities. Carotenoid content was higher in L. Racemosa in both seasons, which represents an additional mechanism against damage to the photosynthetic machinery. The chlorophyll content was not affected by salinity in either species.
\end{abstract}

Keywords: chlorophyll fluorescence, photosynthetic pigments, photosystem.

\section{DESEMPENHO FOTOSSINTÉTICO DE Rhizophora mangle E Laguncularia racemosa EM CONDIÇÕES DE CAMPO}

\begin{abstract}
RESUMO - Em plantas adultas de Rhizophora mangle L. e Laguncularia racemosa Gaerth. crescendo em condições de campo, a eficiência fotoquímica do fotossistema 2 (FS2), determinada pela razão fluorescência variável : fluorescência máxima $\left(F_{v} / F_{m}\right)$, aumentou durante o dia em resposta à salinidade, durante a estação chuvosa. Durante a estação seca, os valores de Fo foram superiores aos observados durante a estação chuvosa. Além disso, Fo reduziu-se ao longo do dia em ambas as estações e espécies, exceto para $R$. mangle durante a estação seca. Uma correlação positiva entre os valores de $F_{v} / F_{m} e$ da salinidade foi obtida em R. mangle e L. racemosa durante as estações seca e chuvosa, mostrando que o desempenho fotossintético é mantido em ambas as espécies sob altas salinidades. O conteúdo de carotenóides foi maior em L. racemosa, em ambas as estações, representando um mecanismo adicional contra danos à maquinaria fotossintética. O conteúdo de clorofila não foi afetado pela salinidade das espécies estudadas.
\end{abstract}

Palavras-chave: Fluorescência da clorofila, pigmentos fotossintéticos e fotossistema.

\footnotetext{
${ }^{1}$ Recebido em 09.03.2007 e aceito para publicação em 19.05.2008.

${ }^{2}$ Departamento de Ciências da Saúde, Biológicas e Agrárias da Universidade Federal do Espírito Santo (UFES), São Mateus-ES.

${ }^{3}$ Departamento de Ciências Biológicas da UFES. E-mail:<biovegetal@terra.com.br>

${ }^{4}$ Programa de Pós-Graduação em Ciências Biológicas da UFES.
} 


\section{INTRODUCTION}

Rhizophora mangle L. and the Laguncularia racemosa Gaerth. mangroves are two major species in the district of Vitoria, Espírito Santo, Brazil and dominant in the American Atlantic coastlines. These species grow in environments with widely ranging salinity, from near freshwater to above seawater salinity (LOVELOCK and FELLER, 2003; SUARÉZ, 2003; SOBRADO, 2004; SOBRADO, 2005). Salinity constitutes the main stressor and regulator of the development and productivity of mangrove forests (MEDINA et al., 1990; SOBRADO and BALL, 1999). Mangrove species more tolerant to salinity may function with less efficient water transport, which may be related to more conservative water use (SOBRADO, 2004). Krauss and Allen (2003) suggested high salinity tends to favor the development, establishment and physiology of R. mangle. However, other studies show that $\mathrm{L}$ racemosa is more tolerant to the negative effects of salinity (SOBRADO, 2004). Evidence for less salt sensitivity in mangrove species includes biochemical adaptations by wich mangroves counter the high osmolarity of salt, like accumulation of compatible solutes or enhanced gland secretion (TAKEMURA et al., 2000; KRAUSS and ALLEN, 2003; SOBRADO, 2004). In contrast, responses of mangrove to salinity reflect alterations in photosynthesis, photosynthetic pigment content, trasnpiration rate, and enzyme activities. Generally, these negative effects also associated with other environmental factors, e.g., high light levels (TAKEMURA et al., 2000; KRAUSS and ALLEN, 2003).

The photosynthetic performance of $R$. mangle and $L$. racemosa mangrove species in the equatorial region of Brazil is little understood. It is known that integrity of membranes, activity of several enzymes, nutrient acquisition, photosynthetic pigment content, gas exchange and photosynthetic apparatus function are affected by high $\mathrm{NaCl}$ concentrations (ZHU, 2001). In halophytes, some studies have showed that salinity inhibits photosystem 2 (PS2) activity, while others indicate the opposite (TAKEMURA et al., 2000; LU et al., 2002; QIU-FANG et al., 2005). Avicennia corniculatum and Bruguiera gymnorrhiza showed a decrease in the photosynthesis, whereas A. marina was not affected by the salinity (TAKEMURA et al., 2000). Other studies showed that salt stress by itself has little effect on the PS2 photochemical efficiency and on photosynthetic pigment content under relatively low light levels. But, under high irradiance, it might cause damage in to PS2, as well as alterations in photosynthetic pigment composition (MISHRA et al. 1991; MORALES et al., 1992; BELKODJA et al., 1994; TUFFERS et al., 2001; NAIDOO et al., 2002). However, most of these studies were done in greenhouses, under controlled conditions, using mature mangroves propgules as a source of the plant material. Information about the physiological behavior of mature plants of $R$. mangle and $L$. racemosa under field conditions is scarce. Thus, the objective of the present study was to evaluate the photosynthetic performance of $R$. mangle and $L$. racemosa during the day in the dry and rainy seasons of the year and relate this performance to variations in interstitial water salinity.

\section{MATERIAL AND METHODS}

The study was conducted in the mangrove forest around of the Universidade Federal do Espírito Santo $\left(20^{\circ} 15^{\prime} 48^{\prime \prime} \mathrm{S}\right.$ and $\left.40^{\circ} 18^{\prime} 17^{\prime \prime} \mathrm{N}\right)$, Vitoria district, Espirito Santo, Brazil. Tidal amplitudes at the study area range between 0.3 and $>1 \mathrm{~m}$. Mangrove forest is abundant on clay and loam areas situated above mean high water level. The relative air humidity at the study site was approximately $89 \%$ and annual average air temperature $26^{\circ} \mathrm{C}$. During the investigation period, annual precipitation was $1250 \mathrm{~mm}$, distributed in a dry (April to September) and a rainy (October to March) season. Mangrove forest at the study site is composed of three tree species: Rhizophora mangle L. (Rhizophoraceae), Laguncularia racemosa Gaerth. (Combretaceae) and Avicennia germinans Stearn. (Avicenniaceae). R. mangle and L. Racemosa are the dominant trees at the study site, while A. Germinans is little represented. All data were collected from ten trees, which varied in height from 2-4 m. Interstitial water was collected in the morning (9 a. m.), midday (1 p. m.) and afternoon (5 p. m.) using $2.5 \mathrm{~cm}$ diameter PVC tube inserted at $-0.2 \mathrm{~m}$ sediment depth, according to the method of Miller and Ullman (2004). Salinity measures of interstitial water were accomplished immediately after collecting the water in the tubes, using a portable condutometer $S C H O T$ Mod. LFI.

Chlorophyll fluorescence parameters were determined in situ on fully expanded young leaves of $R$. mangle and $L$. Racemosa, in the morning, midday and afternoon using a portable Chlorophyll Fluorescence System (Handy-PEA, Hansatech, Norfolk, England) after 30 min of dark adaptation, using specially designed 
clips attached to the leaves. These same leaves were used for the determination of photosynthetic pigment contents (below). Each leaf was exposed to a saturation pulse of light $\left(750 \mu \mathrm{mol} \mathrm{m}^{-2} \mathrm{~s}^{-1}\right.$; the value was obtained from a saturation curve) for $5 \mathrm{~s}$. Initial fluorescence $(F o)$ and PS2 photochemical efficiency $\left(F_{v} / F_{m}\right)$ were calculated automatically.

Chlorophyll and carotenoid contents were determined in the morning using the spectrophotometric method suggested by Arnon (1949). Chlorophyll a (Chl $a)$, chlorophyll b $(C l h b)$, chlorophyll a/b ratio and carotenoids ( $\mathrm{Car}$ ) were calculated using the following equations, suggested by Hendry Grime (1993): $C h l$ $a(\mathrm{mg} / \mathrm{L})=12,7 \times \mathrm{A}_{663}-2,69 \times \mathrm{A}_{645} ;$ Chl $b(\mathrm{mg} / \mathrm{l})=22,9$ $\mathrm{xA}_{645}-4,68 \times \mathrm{A}_{663} ; \operatorname{Car}=\left[\mathrm{A}_{480}+0,114 \mathrm{x} \mathrm{A}_{663}-0,638\right.$ $\left.\mathrm{x} \mathrm{A}_{645}\right) \mathrm{x} \mathrm{V} / 112,5 \mathrm{x}$ Weight of the fresh matter of the leaf $(g)$ ], where $\mathrm{V}=$ volume of the acetone extract in $\mathrm{cm}^{3}$ and $\mathrm{A}=$ absorbance at the specified wavelength $(\mathrm{nm})$, measured with a $1 \mathrm{~cm}$ cuvette.

Each data collection consisted of ten repetitions, in a randomized block design. For salinity, $F o$ and $F_{v}$ $F_{m}$, statistical comparisons were made between dry and rainy seasons and between times during the day. Chlorophyll and carotenoid content values were compared between species and between seasons. Salinity and $F_{v} / F_{m}$ values were correlated in both species and seasons. Results were examined by one-way analysis of variance (ANOVA) and differences between means were assessed using Tukey test at 5\% significance level (STATSOFT, 1995).

\section{RESULTS AND DISCUSSION}

Significant increase in salinity was observed in the rainy season at $1 \mathrm{p}$. m. and $5 \mathrm{p} . \mathrm{m}$. in relation to that at 9 a. m. (Table 1). Furthermore, the salinity values obtained in this season were higher than those in the dry season. During the rainy season, PS2 photochemical efficiency $\left(F_{v} / F_{m}\right)$ of dark-adapted leaves sampled at 9 a. m. were 0.73 and 0.69 forR. mangle and L. Racemosa, respectively (Table 1 ). These values were significantly lower than those obtained at 1 and $5 \mathrm{p}$. m. and were inversely related to initial fluorescence values $(\mathrm{Fo})$.

During the dry season, Fo mean values were higher than those observed in the rainy season for both mangrove species. In the dry season, $F o$ values decreased significantly in $L$. racemosa during the day, from 1027 in the morning, to 875 and 675 in the midday and afternoon, respectively (Table 1 ). In contrast, $F_{v}$ $F_{m}$ values increased significantly during the day for L. racemosa: $0.66,0.74$ and 0.80 at 9 a. $\mathrm{m} ., 1$ and $5 \mathrm{p}$. m., respectively. For $R$. mangle, the $F_{v} / F_{m}$ values were 0.68 at 9 a. m. and 0.77 at 1 and 5 p. m. (Table 1 ). Carotenoid content was higher to L. racemosa in both seasons. There were no significant differences for chlorophyll content between species and between seasons.

$F_{v} / F_{m}$ reflects the PS2 potential efficiency and it is used as indicators of plant photosynthetic performance (KAO and TSAI, 1999; SHIRKE and PATHRE, 2003; RIBEIRO et al., 2004). In this study, the increase observed in $F_{v} / F_{m}$ during the day for $R$. mangle and L. racemosa, in both seasons, can be attributed to a decrease in $F o$, although the $F o$ values did not present a statistically reduction in $R$. mangle during the dry season. Fo originates exclusively from the PS 2 light harvest complex (LHC2) after the application of low red light on leaves adapted to the dark (LICHTENTHALER et al., 2005) and its values are, generally, strongly related to photoinhibition phenomena. In addition, during the rainy season, $F_{v} / F_{m}$ of dark-adapted leaves increased similarly during the day in response to increases in salinity for both species. These results strongly suggest that $R$. mangle and L. racemosa increase their photosynthetic efficiency in response to increases in salinity levels.

Several studies have shown that high salinity causes a decrease of photosynthetic efficiency in mangrove species grown in greenhouses under different concentrations of $\mathrm{NaCl}$. However, the effects of salinity on photosynthetic parameters of mangrove species under field conditions are contradictory. The main reason for this contradiction is the large variation of field environmental conditions. Thus, results obtained in a specific mangrove are cannot be extrapolated to mangroves situated in other regions.

In this study, a positive correlation $\left(r^{2}=0.99\right)$ (not shown) among $F_{v} / F_{m}$ and salinity values was obtained for both species and seasons, indicating that $R$. mangle and $L$. racemosa presented high tolerance and adaptability at high salinity. Halophytic plants are tolerant to salinity because they are able to take up water through the accumulation of inorganic ions or other compatible solutes such as betaine and proline. Consequently, the osmotic potential decreases, which in turn attracts water into the cell and enables to maintain pressure potential (MOGHAIEB et al., 2004).

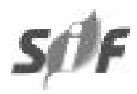

R. Árvore, Viçosa-MG, v.32, n.3, p.577-582, 2008 
Table 1 - Photosynthetic efficiency $\left(F_{v} / F_{m}\right)$, initial fluorescence $(F o)$, chlorophyll content (Chl a, Chl b, Chl a/b ratio) and carotenoid content (Car) in leaves of Rhizophora mangle L. and Laguncularia racemosa Gaerth, subjected to different salinity levels under field conditions. $(\mathrm{n}=10)$

Tabela 1 - Eficiência fotossintética $\left(F_{v} / F_{m}\right)$, fluorescência inicial (Fo), conteúdo de clorofila (Chl a, Chl b, Chl a/b ratio) e conteúdo de carotenóides (Car) em folhas de Rhizophora mangle L. e Laguncularia racemosa Gaerth. sujeitas a diferenças da salinidade em condições de campo $(n=10)$

\begin{tabular}{|c|c|c|c|c|c|c|c|c|}
\hline \multirow[t]{2}{*}{ Parameters } & \multicolumn{3}{|l|}{ Dry season } & \multirow{2}{*}{ mean } & \multicolumn{3}{|l|}{ Rainy season } & \multirow{2}{*}{ mean } \\
\hline & 9 a.m. & 1 p.m. & 5 p.m. & & 9 a.m. & 1 p.m. & 5 p.m. & \\
\hline \multicolumn{9}{|c|}{ Rhizophora mangle L. } \\
\hline Salinity & $10.5 \pm 3.4$ & $12.04 \pm 1.9$ & $11.7 \pm 1.4$ & $11.4 \pm 0.81 \mathrm{~B}$ & $13.4 \pm 0.3 \mathrm{~b}$ & $19.8 \pm 3.6 \mathrm{a}$ & $20.94 \pm 0.8 \mathrm{a}$ & $18.04 \pm 4.0 \mathrm{~A}$ \\
\hline$F v / F m$ & $0.68 \pm 0.02 b$ & $0.77 \pm 0.03 \mathrm{a}$ & $0.77 \pm 0.03 \mathrm{a}$ & $0.74 \pm 0.05$ & $0.73 \pm 0.02 \mathrm{~b}$ & $0.8 \pm 0.003 \mathrm{a}$ & $0.82 \pm 0.001 \mathrm{a}$ & $0.78 \pm 0.04$ \\
\hline Fo & $986 \pm 267$ & $886 \pm 192$ & $844 \pm 200$ & $905 \pm 72.94 \mathrm{~A}$ & $840 \pm 133$ a & $581 \pm 0.0 \mathrm{~b}$ & $546 \pm 11.8 b$ & $655 \pm 160.5 \mathrm{~B}$ \\
\hline Chl $a$ & $0.96 \pm 0.2$ & - & - & - & $1.10 \pm 0.13$ & - & - & - \\
\hline Chl $b$ & $0.64 \pm 0.1$ & - & - & - & $0.77 \pm 0.14$ & - & - & - \\
\hline Chl $a / b$ ratio & $1.47 \pm 0.12$ & - & - & - & $1.4 \pm 0.0$ & - & - & - \\
\hline Car & $0.22 \pm 0.03 *$ & - & - & - & $0.26 \pm 0.03 *$ & - & - & - \\
\hline \multicolumn{9}{|c|}{ Laguncularia racemosa Gaerth. } \\
\hline Salinity & $10.5 \pm 3.4$ & $12.04 \pm 1.9$ & $11.7 \pm 1.4$ & $11.4 \pm 0.81 \mathrm{~B}$ & $13.4 \pm 0.3 \mathrm{~b}$ & $19.8 \pm 3.6 \mathrm{a}$ & $20.94 \pm 0.8 \mathrm{a}$ & $18.04 \pm 4,0 \mathrm{~A}$ \\
\hline$F v / F m$ & $0.66 \pm 0.02 b$ & $0.74 \pm 0.001 \mathrm{a}$ & $0.8 \pm 0.004 \mathrm{a}$ & $0.73 \pm 0.07$ & $0.69 \pm 0.02 b$ & $0.8 \pm 0.01 \mathrm{a}$ & $0.83 \pm 0.0 \mathrm{a}$ & $0.77 \pm 0.07$ \\
\hline Fo & $1027 \pm 38.5 \mathrm{a}$ & $875 \pm 33.5 b$ & $675 \pm 24 \mathrm{c}$ & $859 \pm 176.5 \mathrm{~A}$ & $893 \pm 17.5 \mathrm{a}$ & $653 \pm 51 \mathrm{~b}$ & $530 \pm 10.8 \mathrm{c}$ & $692 \pm 184.6 \mathrm{~B}$ \\
\hline Chl $a$ & $1.03 \pm 0.2$ & - & - & - & $1.13 \pm 0.16$ & - & - & - \\
\hline Chl $b$ & $0.59 \pm 0.19$ & - & - & - & $0.82 \pm 0.13$ & - & - & - \\
\hline Chl $a / b$ ratio & $1.5 \pm 0.0$ & - & - & - & $1.47 \pm 0.06$ & - & - & - \\
\hline Car & $0.3 \pm 0.04 *$ & - & - & - & $0.34 \pm 0.03 *$ & - & - & - \\
\hline
\end{tabular}

Small letters indicate statistical difference along the day within of each season, while capital letters indicate statistical difference between seasons.

Significant differences in carotenoid content between species in each season are represented by an asterisk (*) (Tukey test at $5 \%$ probability level)

Leaf chlorophyll content (Chl a, Chl b and $a / b$ ratio) on a fresh mass basis showed no significant difference for both (daily and seasonal) periods (Table 1). Lu et al. (2002) observed that salt stress had no effects on the photosynthetic pigment composition in halophyte Suaeda salsa, grown outdoors in plastic pots, subjected to salt concentrations up to $400 \mathrm{mM}$. Thus, chlorophyll content in R. mangle and $L$. racemosa seems to be insensitive to salinity variations during the day and in both dry and rainy seasons.

Rhizophora mangle and $L$. racemosa differed in carotenoid content (Table 1). Higher carotenoid content was observed in L. racemosa in both seasons. Carotenoids play important roles in plants: they act as pigment antenna, enhancing the reception of luminous energy for the reaction centers, and protect chlorophyll against photoxidative damage (GONÇALVES et al., 2001; BEHERA and CHOUDHURY, 2002). Durng the protective action, they are degraded. It is possible that $L$. racemosa is adapted to maintain higher carotenoid levels in its cells. On the other hand, low carotenoid contents can be a consequence of $\beta$-carotene degradation and subsequent zeaxantin synthesis (through de-epoxidation of violaxanthin to antheraxanthin and to zeaxanthin), which are also involved in protection against photoinhibition. This is a photoprotective mechanism and allows excess energy to be dissipated.Conversion of violaxanthin to zeaxanthin has been observed in other mangrove species under high salinity (SOBRADO and BALL, 1999).

It is probable that the increase in both synthesis and accumulation of antioxidative pigments (carotenoids) in $L$. racemosa during both dry and rainy seasons represents an additional mechanism against damage to the photosynthetic machinery. Since $F_{v} / F_{m}$ ratios of $0.75-0.85$ have been considered normal for unstressed plants (HUNT, 2003; OLIVEIRA et al., 2006), it can be suggested that $R$. mangle and $L$. racemosa were able to maintain photosynthetic activity in response to salinity increases because of their protection mechanisms.

\section{ACKNOWLEDGEMENTS}

The authors would like to thank to Fundo de Apoio à Pesquisa e Tecnologia do Município de Vitória (FACITEC) for the financial support, and the Laboratório de Ecofisiologia Vegetal of the Universidade Federal do Espírito Santo for supporting this work. 


\section{REFERENCES}

ARNON, D.I. Cooper enzymes in isolated chloroplast. Polyphenoloxidase in Beta vulgaris. Plant Physiology, v. 24, p. 1-15, 1949.

BEHERA, R.K.; CHOUDHURY N.K. High irradiance induced pigment degradation and loss of photochemical activity of wheat chloroplasts. Biology Plantarum, v. 45, p. 45-49, 2002.

BELKHODJA, R.; MORALES, F.; ABADIA, A.; GOMEZ-APARISI, J.; ABADIA, J. Chlorophyll fluorescence as a possible tool for salinity tolerance screening in barley (Hordeum vulgare L.). Plant Physiology, v. 104, p. 667-673, 1994.

GONÇALVES, J.F.; MARENCO, R.A.; VIEIRA, G. Concentration of photosynthetic pigments and chlorophyll fluorescence of mahogany and tonka bean under two light environments.

Revista Brasileira de Fisiologia Vegetal, v. 13, p. 149-157, 2001.

HENDRY, G.A.F.; PRICE, A.H. Stress indicators: chlorophylls and carotenoids. In: GONÇALVES, J.F.; MARENCO, R.A.; VIEIRA, G.

Concentration of photosynthetic pigments and chlorophyll fluorescence of mahogany and tonka bean undes two lighy environments. Revista Brasileira de Fisiologia Vegetal, v. 13, p. 149-157, 2001.

HUNT, D. Measurements of photosynthesis and respiration in plants. Physiologia

Plantarum, v. 117, p. 314-325, 2003.

KAO, W.; TSAI, H. The photosythesis and chlorophyll a fluorescense in seedlings of Kadelia candel (L.) Druce grown under different nitrogen and $\mathrm{NaCl}$ controls.

Photosynthetica, v. 37, p. 405-412, 1999.

KRAUSS, K.; ALLEN, J.A. Influences of salinity and shade on seedling photosynthesis and growth of two mangrove species, Rhizophora mangle and Bruguiera sexangula, introduced to Hawaii. Aquatic botany, v. 77, p. 311-324, 2003.
LEE, G.; CARROW, R.N.; DUNCAN, R.R. Photosynthetic responses to salinity stress of halophytic seachore paspalum ecoypes. Plant Science, v. 166, p. 1417-1425, 2004.

LICHTENTHALER, H.K.; BUSCHMANN, C.; KNAPP, M. How to correctly determine the different chlorophyll fluorescence parameters and the chlorophyll fluorescence decrease ratio $\mathrm{R}_{\mathrm{Fd}}$ of leaves with the PAM fluorometer.

Photosynthetica, v. 43, p. 379-393, 2005.

LOVELOCK, C. E., FELLER, I. C. Photosynthetic performance and resource utilisation of two mangrove species coexisting in a hypersaline scrub forest. Oecologia, v. 134, p. 455-462, 2003.

LU, C.; QIU, N.; LU, Q.; WANG, B.; KUANG, T. Does salt stress lead to increased susceptibility of photosystem II to photoinhibition and changes in photosynthetic pigment composition in halophyte Suaeda salsa grown autdoors? Plant Science, v. 163, p. 1063-1068, 2002.

MEDINA, E.; CUEVAS, E.; POPP, M.; LUGO, A.E. Soil salinity, sun exposure, and growth of Acrostichum aureum, the mangrove fern.

Botanical Gazette, v. 151, p. 41-49, 1990.

MILLER, D.C., ULLMAN, W.J. Ecological consequences of groundwater discharge to Delaware Bay, USA. Ground Water, v. 42, p. 959-970, 2004.

MISHRA, S.K.; SUBRAHMANYAM, D.; SINGHAL, G.S. Interactionship between salt and light stress on the primary process of photosynthesis. Journal of Plant Physiology, v. 138, p. 92-96, 1991.

MOGHAIEB, R.E.A.; SANEOKA, H.; FUJITA K. Effect of salinity on osmotic adjustment, glycinebetaine accumulation and the betaine aldehyde dehydrogenase gene expression in two halophytic plants, Salicornia europaea and Suaeda maritime. Plant Science, v. 166, p. 1345-1349, 2004. 
MORALES, F.; ABADIA, A.; GOMES-APARIS, J.; ABADIA, A.J. Effects of combined $\mathrm{NaCl}$ and $\mathrm{CaCl}_{2}$, salinity on photosynthetic parameters of barley grown in nutrient solution. Physiologia Plantarum, v. 86, p.419-426, 1992.

NAIDOO, G.; TUFFERS, A.V.; Von WILLERT, D.J Changes in gas exchange and chlorophyll fluorescence characteristics of two mangroves and a mangrove associate in response to salinity in the natural environment. Trees, v. 16, n. 140-146, 2002.

OLIVEIRA, C.R.M.; BARBOSA, J.P.R.A.D.; SOARES, A.M.; OLIVEIRA, L.E.M.; MACEDOS, R.L.G. Trocas gasosas de cafeeiros ( coffea arábica L.) e seringueiras (Hevea brasiliensis Muell. Arg.) em diferentes sistemas de cultivo na região de Lavras, MG. Revista Árvore, v. 30, n. 2, p.197-206, 2006.

QIU-FANG, Z.; YUAN-YUAN, L.; CAI-HONG, P.; CONG-MING, L.; BAO-SHAN, W. NaCl enhances thylakoid-bound SOD activity in the leaves of $\mathrm{C}_{3}$ halophyte Suaeda salsa L. Plant Science, v.168, n.2, p.423-430, 2005.

RIBEIRO, R.F.; SOUZA, G.M.; MANZATTO, A.G.; MACHADO, E.C.; OLIVEIRA, R.F. Chlorophyll fluorescence of tropical tree species in a semi-deciduous Forest gap. Revista Árvore, v. 28, n. 1, p. 21-27, 2004.

SHIRKE, P.A.; PATHRE, U.V. Diurnal and seasonal changes in photosynthesis and photosystem 2 photochemical efficiency in Prosopis juliflora leaves subjected to natural environmental stress. Photosynthetica, v. 41, p. 83-89, 2003.
SOBRADO, M.A. Relation of water transport to leaf gas exchange properties in three mangrove species. Trees - Structure and

Function, v. 14, p. 258-262, 2004.

SOBRADO, M. A. Leaf characteristics and gas exchange of the mangrove Laguncularia racemosa as affected by salinity.

Photosynthetica, v. 43, n. 2, p. 217-221, 2005.

SOBRADO, M. A.; BALL, M. C. Light uses in relation to gain in themangrove, Avicennia marina, under hypersaline conditions.

Australian Journal of Plant

Physiology, v. 26, p. 245-251, 1999.

STATSOFT: Statistica for Windows. StatSoft Inc, Tulsa 1995.

SUÁREZ, N. Leaf longevity, construction, and maintenance costs of three mangrove species under field conditions. Photosynthetica, v. 41, p. 373-381, 2003.

TAKEMURA, T.; HANAGATA, N.; SUGIHARA, K.; BABA, S.; KARUBE, D.Z. Physiological and biochemical responses to salt stress in the mangrove, Bruguiera gymnorrhiza. Aquatic Botany, v. 68, p. 15-28, 2000.

TUFFERS, A.; NAIDOO, G.; Von WILLERT, D. J. Low salinities adversely affect photosynthetic performance of the mangrove, Avicennia marina. Wetlands Ecology and Management, v. 9, p. 225-232, 2001.

ZHU, J. Plant salt tolerance. Trends in Plant Science, v. 6, p. 66-71, 2001. 